\title{
The Religious Education of Polish Youth in the Face of Changes in Religiosity ${ }^{1}$
}

In recent years, there has been a significant change in the religiosity of Poles, especially among the youth. Religious education for the youth, however, has remained basically unchanged. Therefore, there is an urgent need to determine the causes of this change in religiosity and respond properly to it. This article first presents the results of sociological research on the religiosity of Polish youth conducted in the last few years, particularly 2013-2016. These results prove that Polish young people believe increasingly less in God, participate increasingly less frequently in the liturgy, and increasingly contest the moral teachings of the Church. The article then proceeds to explain the reasons for these changes, among which is what is broadly understood as a contemporary culture in which rationalism, pluralism, and tolerance dominate. The final part of the article presents ideas to enrich religious education with elements that will address the challenges of the present and make it possible to reach Polish youth.

Key words: youth, religiosity, religious education, catechesis.

\section{Introduction}

Poland is widely considered a Catholic country. This attribute stems not only from history, but also from current statistics. The statistical yearbook "The Catholic Church in Poland: 1991-2011" proves that,

This article was written using data obtained from research financed by the $\mathrm{Na}-$ tional Science Center in Poland. The project registration number is: 2016/21/B/ HS1/00834. 
among all respondents who took part in the National Census conducted in 2011, up to $95.95 \%$ claimed affiliation with the Roman Catholic Church of the Latin rite. ${ }^{2}$ The data obtained during this census are undoubtedly the most reliable, but they primarily concern individuCatechetics als' formal initiation into the Church, which occurs through reception of the sacrament of Baptism. However, many surveys concerning the religiosity of Poles carried out, for example, by Poland's Centrum Badania Opinii Spolecznej [Center for Public Opinion Research; hereafter abbreviated as CPOR] show that Catholics who completely follow and practice the faith and moral principles of the Church make up less than half of Poles. ${ }^{3}$ These statistics point to the privatization or individualization of religion with regard to the professed truths of faith or moral principles. ${ }^{4}$ Particularly dynamic changes in religiosity took place in Poland in 2005, after the death of John Paul II. ${ }^{5}$ These changes in religiosity in Poland have continued to progress as evidenced, for example, by the percentage of Poles who participate in the Eucharist every Sunday, which has increased from $7.8 \%$ in 1980 to $16.3 \%$ in 2013 . This suggests, therefore, that Catholicism is becoming a religion that Poles freely choose, rather than a religion that they simply inherit.

The greatest change in religiosity in Poland concerns Polish youth. This article will examine the changes in religiosity of youth that have been observed in recent years. Data for this study have been obtained primarily from two reports prepared by the CPOR entitled "Youth 2013" " and "Youth 2016," 7 respectively.

2 Instytut Statystki Kościoła Katolickiego SAC, Główny Urząd Statystyczny, Kościót katolicki w Polsce 1991-2011. Rocznik statystyczny, Warsaw 2014, pg. 82.

3 Centrum Badania Opinii Spolecznej, Zmiany w zakresie podstawowych wskaźników religijności Polaków po śmierci Jana Pawła II. Komunikat $z$ badań. $N r$ 26/2015, Warsaw, February 2015. http://www.cbos.pl/SPISKOM. POL/2015/K_026_15.PDF.

$4 \quad$ M. Grabowska, Dekada zmian, dekada nieobecności, in Religijność i Kościót 10 lat po śmierci Jana Pawła II, ed. M. Grabowska, Warsaw 2015, pg. 9.

5 P. Mąkosa, Zwischen orthodoxem Katholizismus und Individualisierung der religiösen Überzeugungen der Polen, „Religionen Unterwegs” 23:2017 nr 3 s. 18.

$6 \quad$ Centrum Badania Opinii Spolecznej, Krajowe Biuro ds. Przeciwdziałania Narkomanii, Młodzież 2013, Warsaw 2014.

7 Centrum Badania Opinii Spolecznej, Krajowe Biuro ds. Przeciwdziałania Narkomanii, Młodzież 2016, Warszawa 2016. For this topic, see: P. J. Chmura, Dynamika religijności współczesnej młodzieży polskiej jako wyzwanie duszpasterskie, Cracow 2008. 


\section{The Dynamics of Religiosity Among Polish Youth from 2013-2016}

The so-called "global attitude of faith" is the basic parameter of religiosity - that is, the self-declaration of the level of one's own religious Catechetics faith. This parameter is very general, but it provides insight into what percentage of a surveyed population is made up of believers, agnostics, or non-believers. In research conducted by Poland's CPOR and, since 2003, the National Bureau for Drug Prevention (NBDP), the following results were obtained. ${ }^{8}$

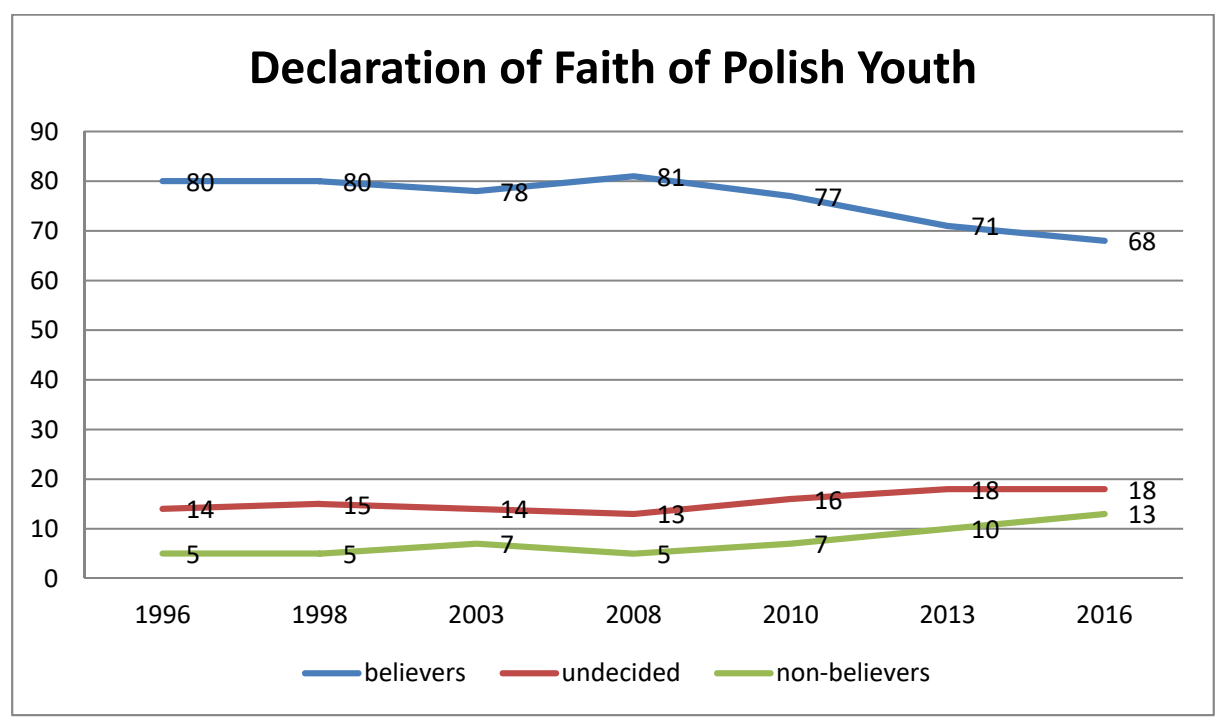

The results presented above (in orange) clearly demonstrate that dynamic changes in religiosity have taken place within the last decade, and the graph below (in grey) depicts those who categorize themselves as believers and deeply faithful in order to show these changes more clearly. The greatest indicator of change is the fact that, within the last decade, the number of youth who describe themselves as non-believers has doubled, averaging $13 \%$, and in cities with more than half a million inhabitants, the percentage of youth who describe themselves as nonbelievers has reached $20 \% .^{9}$ The percentage of those who believe fell

8 These charts are the author's own and are based on the data contained in the following report: A. Głowacki, Religijnośćmłodzieży, in Centrum Badania Opinii Społecznej, Krajowe Biuro ds. Przeciwdziałania Narkomanii, Młodzież 2016, Warsaw 2016, pgs. 130; 133.

$9 \quad$ A. Głowacki, Religijność młodzieży, pg. 136. 
Catechetics

to an average of $68 \%$, while in the largest cities in Poland the number fell to $60 \%$, which is below the so-called "threshold of cultural obviousness." It is important to note that the assertions of the youth surveyed do not pertain to their acceptance of Christianity or even to the image of God presented in Catholicism, but rather to a very general faith in the transcendent. A decade ago, those who believed in the transcendent constituted $80 \%$ of Polish citizens, a statistic that other studies have confirmed. ${ }^{10}$

In addition to the obvious decline in those claiming to be believers, the number of young people in Poland who claim to be deeply religious is slowly growing. In 2013, this number reached 6\%, and in 2016 it increased to $8 \% .{ }^{11}$ This situation proves that religious faith is increasingly becoming a matter of personal choice rather than something that individuals inherit or follow because of tradition.

Another indication of religiosity is participation in the liturgy of one's own religious community. The Catholic Church obliges the faithful $\mathrm{n}$ to participate in the Holy Mass every Sunday and on holy days of obligation. Changes in Polish youth's commitment to this obligation are presented in the graph below.

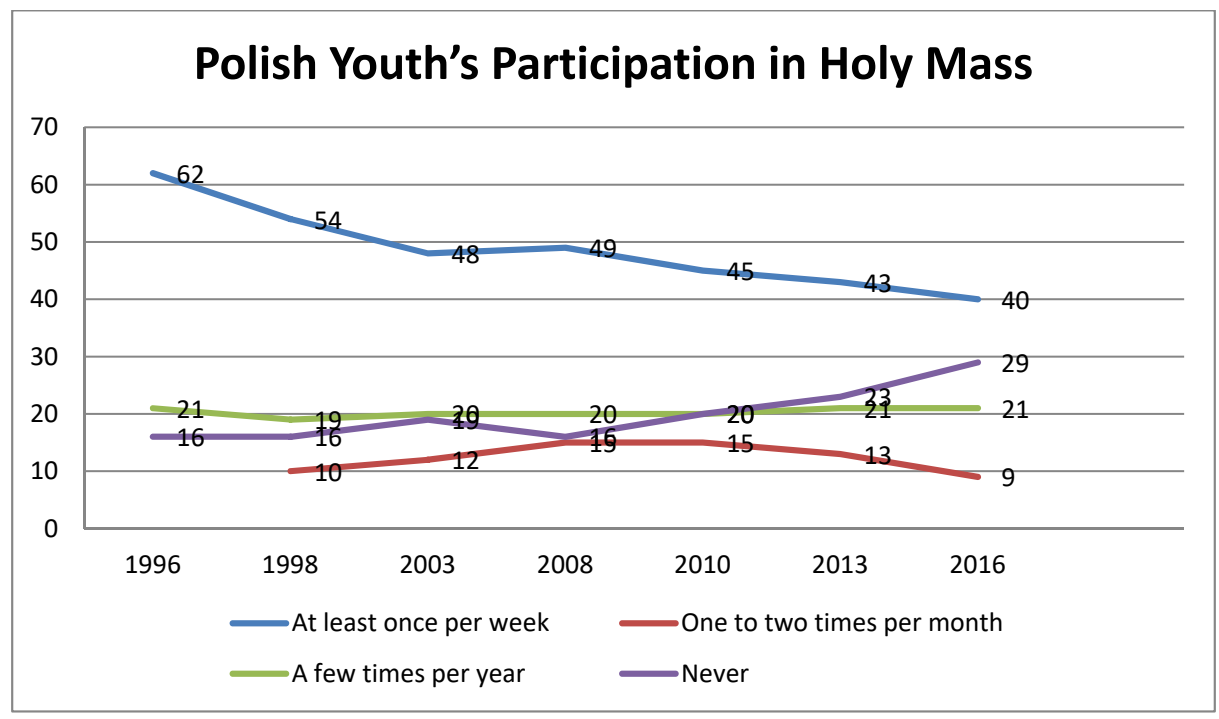

10 J. Mariański, Emigracja z Kościoła. Religijność młodzieży polskiej w warunkach zmian społecznych, Lublin 2008, pg. 86; S. H. Zaręba, W kierunku jakiej religijności? Studia nadkatolicyzmem polskiej młodzieży, Warsaw 2008, pg. 112.

11 A. Głowacki, Religijność młodzieży, pg. 130. 
A crisis in Polish youth's level of religious practice has undoubtedly already begun, as can be seen by the fact that the number of Polish youth who never participate in church services has doubled in the past decade, reaching 29\% in urban and rural areas and even $37 \%$ in cities. Within the largest cities in Poland, the percentage of those who attend Holy Mass at least once a week is only $23 \% .^{12}$

In recent years (2013-2016), the percentage of young people who participate in religious practices several times per week has increased slightly from $6 \%{ }^{13}$ to $8 \%{ }^{14}$ This testifies to the fact that those who consciously and voluntarily choose to belong to religious communities are very involved in them.

Recently, a significant decrease has also occurred in Polish youth's attendance of religion class at school. ${ }^{15}$

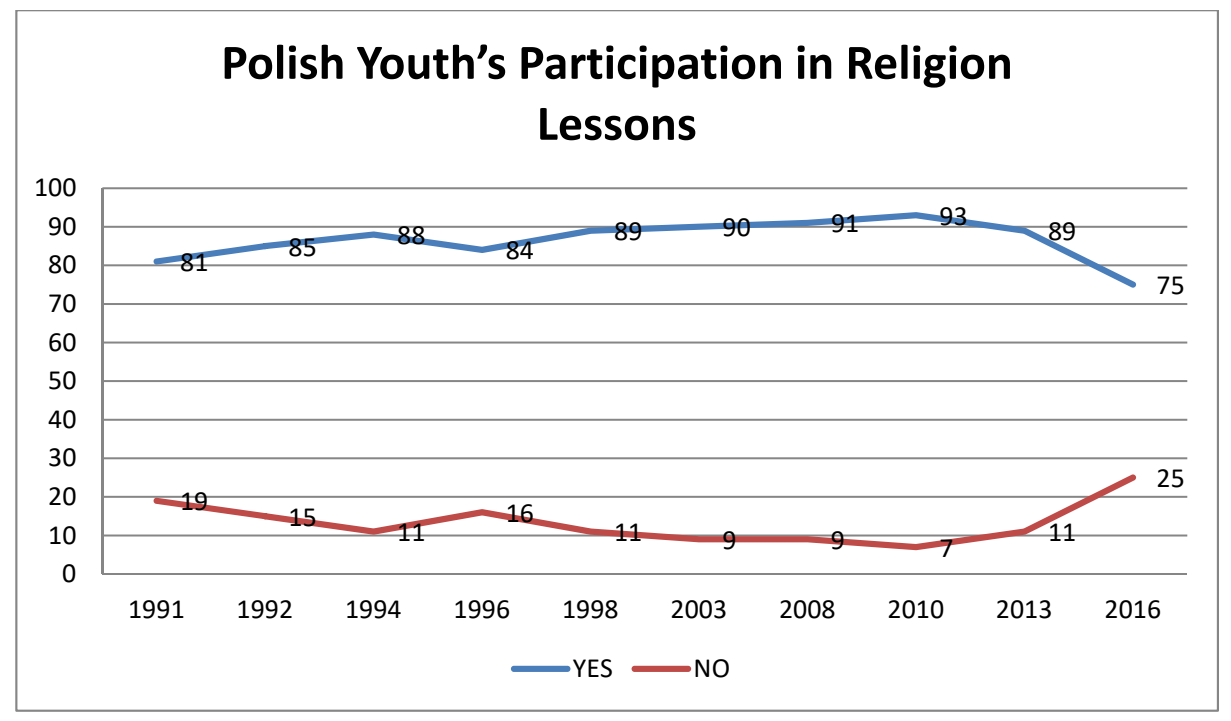

One of the most significant changes that has occurred is clearly the attitude of young Poles toward religion class at school. A decline has taken place in this area in the last few years. Since religious education was reintroduced in Polish schools in 1990, lessons in religion

12 Ibid, pg. 138.

13 R. Boguszewski, M. Feliksiak, M. Gwiazda, J. Kalka, Młodzież o sobie: wartości, obyczajowość, grupy odniesienia, pg. 112.

$14 \quad$ A. Głowacki, Religijność młodzieży, pg. 133.

15 M. Gwiazda, Religia w szkole-uczestnictwo i ocena, w: Centrum Badania Opinii Społecznej, Krajowe Biuro ds. Przeciwdziałania Narkomanii, Młodzież 2016, Warsaw 2016, pg. 141. 
have consistently been popular and class attendance has fluctuated at around $90 \%$. A rapid decline in attendance, however, has occurred in the last few years, and as early as $2013,89 \%$ of Polish youth claimed to participate in religion classes, ${ }^{16}$ while in 2016 this number reached an average of $75 \%$, with an average of barely $49 \%$ in the largest cities in Poland. ${ }^{17}$

Another indicator of religiosity is the acceptance of moral principles. One of the biggest problems is the area of sexuality and pre-marital sex-issues toward which the attitude of young Poles has changed. The following graph presents the range of opinions of young Poles on the issue of premarital sex. ${ }^{18}$

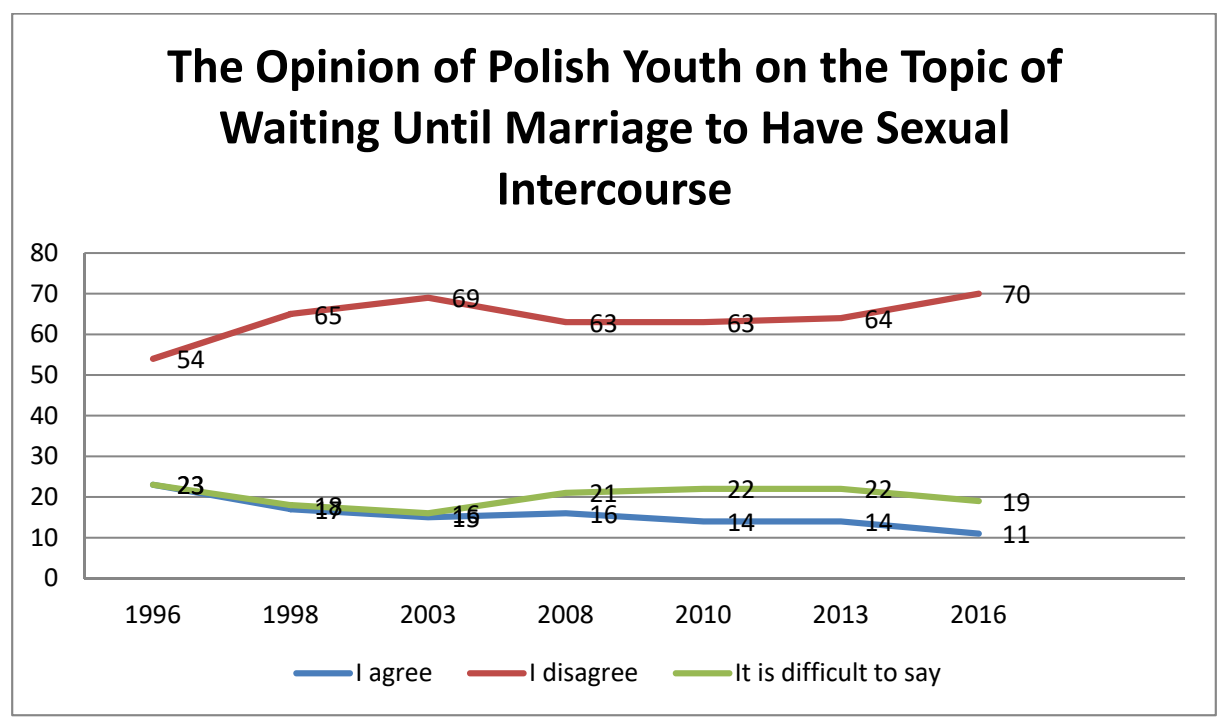

Moral issues always score lowest on surveys on religion. This is due in part to the fact that it is always easier for people to claim religious affiliation or even participate in religious practices than to follow the moral teachings of the Catholic Church. Human sexuality is a especially sensitive area that poses particular challenges to young people. Research conducted by the CPOR has confirmed this fact by

16 R. Boguszewski, M. Feliksiak, M. Gwiazda, J. Kalka, Młodzież o sobie: wartości, obyczajowość, grupy odniesienia, pg. 117.

17 M. Gwiazda, Religia w szkole - uczestnictwo i ocena, in Centrum Badania Opinii Społecznej, Krajowe Biuro ds. Przeciwdziałania Narkomanii, Młodzież 2016, Warsaw 2016 pgs. 141, 143.

18 M. Gwiazda, Młodzież i seks, in Centrum Badania Opinii Społecznej, Krajowe Biuro ds. Przeciwdziałania Narkomanii, Młodzież 2016, Warsaw 2016, pg. 154. 
demonstrating that in 1996 only $23 \%$ of Polish youth believed that sex should take place only after marriage, whereas currently this percentage has decreased to $11 \%$. Studies have shown that other dynamic changes in religiosity have taken place over the past few years. ${ }^{19} \mathrm{How}-$ ever, the results obtained from these surveys do not reflect whether people accept the Church's teachings because the respondents are not asked about what they believe regarding the Sacrament of Marriage and civil marriage. In practice, the percentage of youth who agree with the Church's teaching that sexual relations should take place only within the context of marriage is less. Studies from 2005, during which respondents were asked directly about what they believed about the Catholic Church's teaching on marriage as a condition for sexual intercourse revealed that only $9.2 \%$ of young people agreed with the Church's teaching on this issue. ${ }^{20}$

In summarizing the results of studies on the religiosity of Polish youth, it is clear that religiosity has been declining for many years, while the more dynamic changes that have taken place have become apparent only in the last few years. These changes are characterized by an increasing radicalism. On the one hand, more and more young Poles are leaving the Church, do not participate in religious practices, and contest the Church's moral teaching. On the other hand, those who do choose to belong to the Catholic Church strive to be very involved in the life and activities of their parish communities. These changes confirm observations that religion has become an issue of personal choice and not one of social influence.

\section{The Causes for Changes in Religiosity}

It is important to consider the causes of the changes that have occurred in the religiosity of Polish youth. Undoubtedly today's culture is the main reason for many of these particular issues. Contemporary culture is increasingly more rationalistic and materialistic; it values rational knowledge and material goods most, while it relegates matters of religion to the margins of life. In his exhortation Evangelii Nuntiandi, Pope Paul VI states that, although it began in the Middle Ages and became more dynamic during the French Revolution, the

$19 \quad$ Ibid, pg. 154.

20 S.H. Zaręba, W kierunku jakiej religijności? Studia nad katolicyzmem polskiej mtodzieży, pg. 287; Por. P. Mąkosa, The Catholic Identity of Polish Youth at the Beginning of the 21st Century, in A Glance in the Mirror: Dutch and Polish Religious Cultures. Eds. M. Kalsky, P. Nissen, LIT Verlag Münster - Berlin - Vienna - London 2012, pgs. 85-86. 
secularization of culture is occurring more rapidly and becoming more widespread (55). According to Paul VI, this secularization is primarily the consequence of the development of knowledge, which makes it possible to explain many phenomena through science, which subseCatechetics quently leads to the rejection of God..$^{21}$ In turn, this leads to ideologies that promote life without $\operatorname{God}^{22}$ and try to provide answers to all (even eschatological) questions..$^{23}$

In addition, contemporary culture is becoming more postmodern ${ }^{24}$ and guided by the principles of pluralism and unbridled tolerance. Modern postmodern pluralism consists not only in the acceptance of diversity, but also in encouraging it. As a result, people assume that the more diversity there is, the better. Consequently, very different and often contradictory realities coexist on equal terms in various spheres of life: economic, industrial, political, ideological, and moral. ${ }^{25}$ At the same time, the absolute tolerance that is characteristic of the postmodern age does not allow anyone to criticize the views, behaviors, or attitude of others. As a result, no one has the right to judge anyone or anything. ${ }^{26}$ Such a culture, which is mediated by the powerful influence of the media, leads to individualism and the privatization of every area of life, including - and perhaps above all—religion. ${ }^{27}$

In a rationalistic, materialistic, extremely pluralistic, tolerant, and individualistic culture it is difficult to find every religion, but particularly one that presents a consistent system of beliefs and moral values that it obliges its followers to accept and practice. While respecting other religions, Christianity is a religion that claims that it is the best way to salvation ${ }^{28}$ and sets high moral standards. The Catholic

21

Por. J. Mariański, Sekularyzacja i desekularyzacja w nowoczesnym świecie, Lublin 2006, pg. 25.

Por. P. Neuner, Psychospołeczne i polityczne uwarunkowania chrześcijaństwa dziś, in Chrześcijaństwojutra. Materiaty II Międzynarodowego Kongresu Teologii Fundamentalnej, Eds. M. Rusecki, K. Kaucha, Z. Krzyszowski, I.S. Ledwoń, J. Mastej, Lublin 2001 pg. 237.

Ibid, pg. 239.

See S. Kowalczyk, Idee filozoficzne postmodernizmu, Radom 2004, pgs. 105-110.

See J. Mizińska, Ponowoczesność a prawo do metafory $w$ refleksji nad kultura, "Ethos" 9:1996 no 1-2, pgs. 184-189.

See Z. Sareło, Postmodernizm w pigutce, Poznan 1998, pg. 10.

S.H. Zaręba, W kierunku jakiej religijności? Studia nad katolicyzmem polskiej młodzieży, Warsaw 2008, pgs. 504-505.

Congregation for the Doctrine of the Faith, Dominus Iesus: Declaration on the Unicity and Salvific Universality of Jesus Christ and the Church, Vatican City $2000,17$. 
Church professes and teaches that Jesus Christ is the only Savior of mankind and that, although salvation can be attained through other religions, the fullness of the means of salvation exist only in the Catholic Church. ${ }^{29}$

The results of the surveys on religiosity presented above confirm how contemporary culture strongly influences Polish youth. The decline in the number of youth who claim to believe, which is a measure of a person's sensitivity to the transcendent, reveals that rationalism and materialism are exerting a strong influence on them. Individualism is evident above all in the youth's selective approach to the tenets of faith and moral norms and in their rejection of the Church as an intermediary between God and man. ${ }^{30}$ In contemporary culture, Christianity has become one among many options from which to choose, and, even if individuals choose it, they often manipulate the religion to suit their own preferences. In addition, people also choose what they wish to practice from a variety of religions, mixing the beliefs, convictions, ethical and moral principles,${ }^{31}$ and even contradictory elements of different traditions and cultures. ${ }^{32}$ Today's "believers" create "their own God, their own heaven, their own salvation, and their own little credo." 33 In this sense, P. Neuner states that "The concotion that resembles religion in postmodern times is made up of a small amount of love for one's neighbor, a large quantity of love of animals, a little dose of wandering souls, a large portion of psychology and paraspychology, along with a touch of esotericism, completemented with a Christmas idyll and a large amount of criticism of the [Catholic] Church. It does not matter whether all of these goes together." 34

The current concept of catechesis as well as teaching religion in schools assume that those who participate in the classes are believers in, practice, and want to deepen their faith. However, as the analyses above demonstrate, the majority of youth contest the Catholic Church's moral principles. Research and daily observation prove that

$29 \quad$ Catechism of the Catholic Church, 824.

30 Por. J. Mariański, Charakterystyka religijno-moralna współczesnej młodzieży, in Katecheza mtodzieży, ed. S. Kulpaczyński, Lublin 2003, pgs. 15-70.

Por. P. Neuner, Psychospołeczne i polityczne uwarunkowania chrześcijaństwa dziś, pgs. 259-261.

Por. T. Luckmann, Transformations of Religion and Morality in Modern Europe, "Social Compass" 50:2003 no 3, pgs. 275-285. 
an increasing part of the population rejects religious arguments on many issues, including, for example, the creation of the world or in vitro fertilization. As a result, the discrepancy between the doctrine of the Church and real life is increasing even among those who consider themselves to be believers.

\section{Seeking a New Vision for Religious Education}

In light of the problems mentioned above, one questions how to best orient religious education for youth to meet the present challenges. Given the widespread rationalism and empirical mentality that permeates postmodern culture, it is important to emphasize that the Catholic Church has recognized for centuries that, based on the observation of the cosmos and man, it is possible to come to a rational understanding of God and his basic attributes. In this regard, the First Vatican Council Constitution Dei Filius states: "God, the beginning and end of all things, can be known with certitude by the natural light of human reason from created things [...]." ${ }^{35}$ The Second Vatican Council took up the same position in other documents, including the Dogmatic Constitution on Divine Revelation 6, Gaudium et Spes 19-22, and Ad Gentes 7. Therefore, it is worthwhile to discuss selected arguments that have been developed through a philosophy of God that upholds that observing the world and (from the world) interior human experiences that prove that these phenomena cannot explain themselves or their own existence. In this context, arguments based on entropy and the expansion of the universe support the existence of God. ${ }^{36}$ Another argument that may encourage young people to reflect on and search for God is their own deep desire for happiness and their experience of the fact that true and lasting happiness is very difficult to find. ${ }^{37}$ Moreover, students can be encouraged to either accept the reality that we find fulfillment in God, or recognize that human existence does not make sense- that it is simply a mistake in itself.

Paradoxically, in religious education for youth, it is also important for educators to draw the attention of youth to phenomena that cannot

\footnotetext{
35 Second Vatican Council, Dei Filius, Vatican City, 1870. http://inters.org/VaticanCouncil-I-Dei-Filius (05.15.2018).

36 Por. M. Heller, Teologia a nauki przyrodnicze, in M. Heller, J. Życiński, Drogi myślacych, Cracow 1985, pg. 11.

37 See K. Tarnowski, Człowiek i transcendencja, Cracow 1995, pg. 34.
} 
be explained, particularly recognized miracles. ${ }^{38}$ In this way, youth can come to understand that empirical science does not fully explain all of reality and that there is an entire sphere of life that is outside of cognition and the world experienced through the senses. While youth believe, on the one hand, that everything can be explained through empirical methods, they also understand, on the other hand, that facts cannot be negated.

Due to the pluralism and relativism that characterize postmodern culture, it is also necessary to set forth arguments that defend the Catholic Church's credibility as the Church that was founded by Christ and leads to salvation. "You should be certain that the way that Christianity and the Catholic Church propose is not some kind of illusion, one of many theories devised by people, but rather an objective truth that they can trust completely." ${ }^{39}$ Educators, therefore, must present facts that prove the historical existence of Christ and his resurrection. The historicity of Jesus frees Christianity from claims that it is fictitious, while the resurrection authenticates the truth about Christ's divinity and demonstrates that he is not just a special man and great teacher who lived long ago. ${ }^{40}$ In addition to demonstrating the credibility of Christianity, educators must also show the supernatural origin and continuity of the Catholic Church as the Church that Christ himself founded. This will serve as a fundamental argument for the preservation of tradition and apostolic succession. ${ }^{41}$

In order for religious education to be effective and interesting to young people, educators must include existential issues in education. Often young people treat Christianity as a theory that is detached from the present and their own problems. In this way, the youth do not see Christianity "as something new and attractive that carries the fresh breath of the spirit," but rather as "something that is already wellknow, happened a long time ago, outdated, and not worth believing in." ${ }^{42}$ Consequently, educators should devote a lot of time to addressing

38 See K. Berger, Czy wolno wierzyć w cuda? Poznań 2006; B. McKenna, Cuda się zdarzaja, Warsaw 2000.

39 P. Mąkosa, Katecheza młodzieży gimnazjalnej $w$ Polsce. Stan aktualny i perspektywy rozwoju, Lublin 2009, pg. 436.

40

J. Morawa, Znaki prawdziwości Kościoła, in Teologia fundamentalna, vol. 4, Kościót Chrystusowy, ed. T. Dzidek, Ł. Kamykowski, A. Kubiś et al., Cracow 2003, pg. 170. pg. 169. 
the problems of youth (i.e., love, friendship, loneliness, and suffering) in order to show that God and faith in him are helpful in order to find answers to the questions that trouble them and serve as a real source of help in their lives.

Catechetics Not only must religious education present good content to students, it is also necessary for educators to establish good relationships with their students. Given the prevailing individualism of our age, it is necessary to establish personal bonds that are lacking; for, through such relationships, teachers can give their own personal testimonies, which play a major role in helping youth see the relevance of faith in their lives.

The proposals presented above only begin to address the needs of the religious education of youth, but they are a starting point to renew education and meet the needs of contemporary culture.

\section{Conclusion}

This article presents the results of surveys on the religiosity of Polish youth throughout the past few years. These studies prove that Polish youth are becoming less and less religious. In turn, the article attempts to determine the causes of these observed changes, arguing that they are due primarily to contemporary culture, which is dominated by rationalism, unrestricted pluralism, and extreme tolerance. The last part of this article proposes to enrich religious education by including in it issues that address the contemporary challenges discussed above.

\section{EDUKACJA RELIGIJNA POLSKIEJ MŁODZIEŻY WOBEC PRZEMIAN RELIGIJNOŚCI}

W ostatnich latach zauważalna jest duża dynamika przemian religijności Polaków, zwłaszcza młodego pokolenia. Edukacja religijna przeznaczona dla tej grupy zasadniczo pozostaje jednak bez zmian. Istnieje zatem pilna konieczność określenia przyczyn współczesnych przemian i udzielenia na nie odpowiedzi. W tym artykule przedstawiono najpierw wyniki badań socjologicznych dotyczących religijności polskiej młodzieży z ostatnich kilku lat, a zwłaszcza z lat 2013-2016. Dowodzą one tego, że polska młodzież coraz mniej wierzy w Boga, coraz rzadziej bierze udział w liturgii i kontestuje moralne nauczanie Kościoła. Następnie podjęto próbę wskazania przyczyn tych przemian. Wśród nich na pierwszym miejscu wymieniono szeroko rozumianą dzisiejszą kulturę, w której 
dominują racjonalizm, pluralizm i tolerancja. W ostatniej części artykułu przedstawiono propozycje wzbogacenia edukacji o takie elementy, które podejmują wyzwania współczesności i dają szansę na dotarcie do młodych ludzi.

Słowa kluczowe: religijność młodzieży, edukacja religijna, katecheza, młodzież.

\section{Bibliography:}

1. Berger K., Czy wolno wierzyć w cuda? Poznan 2006.

2. Boguszewski R., M. Feliksiak, M. Gwiazda, J. Kalka, Młodzież o sobie: wartości, obyczajowość, grupy odniesienia, in Centrum Badania Opinii Społecznej, Krajowe Biuro ds. Przeciwdziałania Narkomanii, Młodziė 2013, Warsaw 2014.

3. Center for Public Opinion Research, Krajowe Biuro ds. Przeciwdziałania Narkomanii, Młodzież 2013, Warsaw 2014.

4. Center for Public Opinion Research, Krajowe Biuro ds. Przeciwdziałania Narkomanii, Młodzież 2016, Warsaw 2016.

5. Center for Public Opinion Research, Zmiany w zakresie podstawowych wskaźników religijności Polaków po śmierci Jana Pawła II. Komunikat z badań. Nr 26/2015. Warsaw, February 2015. http://www.cbos.pl/SPISKOM. POL/2015/K_026_15.PDF .

6. Chmura J., Dynamika religijności wspótczesnej młodzieży polskiej jako wyzwanie duszpasterskie, Cracow 2008.

7. Dyk S., Duch - Stowo - Kościót. Biblijny model ewangelizacji, Lublin 2007.

8. Głowacki A., Religijność młodzieży, in Centrum Badania Opinii Społecznej, Krajowe Biuro ds. Przeciwdziałania Narkomanii, Młodzież 2016, Warsaw 2016, pgs. 130-140.

9. Grabowska M., Dekada zmian, dekada nieobecności, in Religijność i Kościót 10 lat po śmierci Jana Pawła II, ed. M. Grabowska, Warsaw 2015.

10. Gwiazda M., Młodzież i sek, in Centrum Badania Opinii Społecznej, Krajowe Biuro ds. Przeciwdziałania Narkomanii, Młodzież 2016, Warsaw 2016.

11. Gwiazda M., Religia w szkole - uczestnictwo i ocena, in Centrum Badania Opinii Społecznej, Krajowe Biuro ds. Przeciwdziałania Narkomanii, Młodziė̇ 2016, Warsaw 2016.

12. Heller M., Teologia a nauki przyrodnicze, in M. Heller, J. Życiński, Drogi myślacych, Cracow 1985.

13. Instytut Statystki Kościoła Katolickiego SAC, Główny Urząd Statystyczny, Kościót katolicki w Polsce 1991-2011. Rocznik statystyczny, Warsaw 2014.

14. Jedynak W., Wybrane aspekty przemian religijności i moralności młodzieży polskiej, in Czy stracone pokolenie? Mtodzież i jej dylematy na poczatku XXI wieku, eds. P. Długosz, H. Kotarski, W. Jedynak, Rzeszow 2014.

15. Congregation for the Doctrine of the Faith, Dominus Iesus, Vatican City 2000.

16. Kowalczyk S., Idee filozoficzne postmodernizmu, Radom 2004.

17. Luckmann Th., Transformations of Religion and Morality in Modern Europe, "Social Compass" 50:2003 no. 3, pgs. 275-285. 
18. Mariański J., Charakterystyka religijno-moralna wspótczesnej młodzieży, in Katecheza młodzieży, Ed. S. Kulpaczyński, Lublin 2003, pgs. 15-70.

19. Mariański J., Emigracja z Kościoła. Religijność młodzieży polskiej w warunkach zmian społecznych, Lublin 2008.

20. Mariański J., Sekularyzacja i desekularyzacja w nowoczesnym świecie, Lublin 2006.

21. Mąkosa P., Katecheza mtodzieży gimnazjalnej w Polsce. Stan aktualny $i$ perspektywy rozwoju, Lublin 2009.

22. Mąkosa P., The Catholic Identity of Polish Youth at the Beginning of the 21st Century, in A Glance in the Mirror. Dutch and Polish Religious Cultures, Eds. M. Kalsky, P. Nissen, LIT Verlag Münster-Berlin-Vienna-London 2012, pgs. 85-86.

23. Mąkosa P., Zwischen orthodoxem Katholizismus und Individualisierung der religiösen Überzeugungen der Polen, "Religionen Unterwegs" 23:2017 no. 3 , pg. 18.

24. McKenna B., Cuda się zdarzaja, Warsaw 2000.

25. Mizińska J, Ponowoczesność a prawo do metafory $w$ refleksji nad kultura, "Ethos" 9:1996 no. 1-2, pgs. 184-189.

26. Morawa J., Znaki prawdziwości Kościoła, in Teologia fundamentalna, Vol. 4, Kościót Chrystusowy, Eds. T. Dzidek, Ł. Kamykowski, A. Kubiś, et al., Cracow 2003.

27. Neuner P., Psychospołeczne i polityczne uwarunkowania chrześcijaństwa dziś, in Chrześcijaństwo jutra. Materiaty II Międzynarodowego Kongresu Teologii Fundamentalnej, Eds. M. Rusecki, K. Kaucha, Z. Krzyszowski, I.S. Ledwoń, J. Mastej, Lublin 2001.

28. Sareło Z., Postmodernizm w pigutce, Poznan 1998.

29. First Vatican Council, Dei Filius, Vatican City, 1870.

30. Świątkiewicz W., O kryteriach wartościowania moralnego, in Młodzież Warszawy - pokolenie pontyfikatu Jana Pawta II, Eds. W. Zdaniewicz, S. H. Zaręba, Warsaw 2005.

31. Tarnowski K., Człowiek $i$ transcendencja, Cracow 1995.

32. Zaręba S.H., W kierunku jakiej religijności? Studia nad katolicyzmem polskiej młodzieży, Warsaw 2008. 